\title{
Editorial
}

\section{Spatially Supported Disaster Management: Introduction to the Special Issue "GI for Disaster Management"}

\author{
Orhan Altan ${ }^{1, *(\mathbb{D}}$, Tullio Joseph Tanzi ${ }^{2}{ }^{\mathbb{D}}$, Madhu Chandra ${ }^{3}$, Filiz Sunar ${ }^{1}$ and \\ Lena Halounová 4 (D) \\ 1 Department of Geomatics, Istanbul Technical University, 34469 Istanbul, Turkey; fsunar@gmail.com \\ 2 LTCI, Telecom Paris, Institut Polytechnique de Paris, 75013 Paris, France; tullio.tanzi@telecom-paris.fr \\ 3 Microwave Engineering and Electromagnetic Theory, Chemnitz, Technical University of Chemnitz, \\ 09126 Chemnitz, Germany; madhu.chandra@etit.tu-chemnitz.de \\ 4 Civil Engineering, Czech Technical University in Prague, Thákurova 7, 16629 Prague, Czech Republic; \\ halounov@gmail.com \\ * Correspondence: oaltan@itu.edu.tr
}

Received: 30 April 2020; Accepted: 4 May 2020; Published: 8 May 2020

This special issue explores most of the scientific issues related to spatially supported disaster management and its integration with geographical information system technologies in different disaster examples and scales. The need for a detailed use of geoinformation in disaster management is a fact [1,2]. Dealing with disasters over space and time represents a long-lasting theme, now approached by means of innovative techniques and modelling approaches (Gi4DM Conference Series, http://www.gi4dm.net/). Several priorities for actions to reduce existing disaster risks and prevent new ones include understanding disaster risk, strengthening disaster risk governance for the management of disaster risk, investing in disaster reduction for resilience, and enhancing disaster preparedness for effective responses [3,4] are outlined.

This special issue explores some of them, with challenging ideas facing different components of spatial patterns related to ecological processes and the published articles are selected and extended versions from the Gi4DM Conference in 2019 in Prague, Czech Republic. Articles [5-7] deal with sea-level rise. In the last decades, forest fires became a major disaster phenomenon and Luis Paduva [8] developed some innovative techniques such as UAV-borne observations and compared them with sentinel data. During crisis response, it is critical to share and understand complex spatial, thematic, and temporal information in a timely, visual and compelling way. Cartography plays an important role in delivering reliable, understandable, appealing and user-friendly visual information through maps. In order to provide seamless communication between heterogeneous audiences at the time of a disaster, Kuveždić Divjak [9] deals with a unique environment for cartographic symbolization. A very interesting study dealing with suitable site selection and planning of urban areas affected by multiple hazards, and their integration into hazard susceptibility maps, can be seen in Yanar [10]. Norman Kerle and his colleagues deal with one of the oldest remote sensing challenges, i.e., structural disaster damage detection and characterization [11].

ISPRS are working closely with many GeoUnions, such as URSI (Union Radio Science International), an organization bringing together experts from remote sensing and geoinformation technology and related sciences and technology. Papers from various events—congresses, Gi4DM conferences, several symposia workshop—are available at https://www.isprs.org/publications/Default.aspx.

This special issue gathers papers from the best researchers in the field who properly faced different aspects of spatial ecology, including problems and uncertainties which in most cases remain unaddressed in disaster management, at large. 
We hope that the readership of the ISPRS International Journal of Geo-Information will enjoy the scientific effort put into properly facing and finding solutions to very different issues of disaster management.

\section{References}

1. Altan, O.; ToZ, G.; Kulur, S.; Seker, D.; Volz, S.; Fritsch, D.; Sester, M. Photogrammetry and geographic information systems for quick assessment, documentation and analysis of earthquakes. ISPRS J. Photogramm. Remote Sens. 2001, 55, 359-372. [CrossRef]

2. Altan, O. Use of Photogrammetry, Remote Sensing and Spatial Information Technologies in Disaster Management, especially Earthquakes. In Geo-Information for Disaster Management; Van Oosterom, P., Zlatanova, S., Fendel, E.M., Eds.; Springer: Berlin/Heidelberg, Germany, 2005. [CrossRef]

3. Ismail-Zadeh, A.; Cutter, S. (Eds.) Disaster Risks Research and Assessment to Promote Risk Reduction and Management; International Science Council: Paris, France, 2015. Available online: http://www.iugg.org/ policy/Report_RiskReduction_WCDRR_2015.pdf (accessed on 15 April 2020).

4. Cutter, S.; Ismail-Zadeh, A.; Alcántara-Ayala, I.; Altan, O.; Baker, D.N.; Briceño, S.; Gupta, H.; Hollaway, A.; Johnston, D.; McBean, G.A.; et al. Pool knowledge to stem losses from disasters. Nature 2015, 522, 277-279. [CrossRef] [PubMed]

5. Baučić, M. Household Level Vulnerability Analysis-Index and Fuzzy Based Methods. ISPRS Int. J. Geo Inf. 2020, 9, 263. [CrossRef]

6. Avşar, N.B.; Kutoğlu, Ş.H. Recent Sea Level Change in the Black Sea from Satellite Altimetry and Tide Gauge Observations. ISPRS Int. J. Geo Inf. 2020, 9, 185. [CrossRef]

7. Nirwansyah, A.W.; Braun, B. Mapping Impact of Tidal Flooding on Solar Salt Farming in Northern Java using a Hydrodynamic Model. ISPRS Int. J. Geo Inf. 2019, 8, 451. [CrossRef]

8. Pádua, L.; Guimarães, N.; Adão, T.; Sousa, A.; Peres, E.; Sousa, J.J. Effectiveness of Sentinel-2 in Multi-Temporal Post-Fire Monitoring When Compared with UAV Imagery. ISPRS Int. J. Geo Inf. 2020, 9, 225. [CrossRef]

9. Kuveždić Divjak, A.; Đapo, A.; Pribičević, B. Cartographic Symbology for Crisis Mapping: A Comparative Study. ISPRS Int. J. Geo Inf. 2020, 9, 142. [CrossRef]

10. Yanar, T.; Kocaman, S.; Gokceoglu, C. Use of Mamdani Fuzzy Algorithm for Multi-Hazard Susceptibility Assessment in a Developing Urban Settlement (Mamak, Ankara, Turkey). ISPRS Int. J. Geo Inf. 2020, 9, 114. [CrossRef]

11. Kerle, N.; Nex, F.; Gerke, M.; Duarte, D.; Vetrivel, A. UAV-Based Structural Damage Mapping: A Review. ISPRS Int. J. Geo Inf. 2020, 9, 14. [CrossRef] 